\title{
Use of otolith strontium : calcium ratio as an indicator of seasonal displacements of the silverside (Odontesthes bonariensis) in a freshwater- marine environment
}

\author{
E. Avigliano ${ }^{\mathrm{A}, \mathrm{B}}$ and A. V. Volpedo $\mathrm{A}, \mathrm{B}, \mathrm{C}$

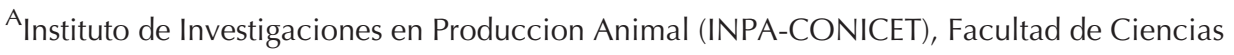 \\ Veterinarias, Universidad de Buenos Aires, Av. Chorroarín 280 (C1427CWO), \\ Buenos Aires, Argentina. \\ ${ }^{B}$ Consejo Nacional de Investigaciones Científicas y Técnicas (CONICET), \\ Buenos Aires, Argentina. \\ ${ }^{\mathrm{C}}$ Corresponding author. Email: avolpedo@fvet.uba.ar
}

\begin{abstract}
Strontium : calcium ( $\mathrm{Sr}: \mathrm{Ca}$ ) ratios were measured in sagittal otoliths of silverside (Odontesthes bonariensis) from a freshwater-marine environment (Paraná River Delta and Río de la Plata River, South America) in order to understand its seasonal movements. Conductivity was recorded and the water $\mathrm{Sr}$ : Ca ratio was determined by inductively coupled plasma-atomic emission spectrometry (ICP-OES). A calibration curve of water $\mathrm{Sr}: \mathrm{Ca}$ ratio versus otolith $\mathrm{Sr}: \mathrm{Ca}$ ratio from four isolated lentic water bodies was made to predict silverside displacements in the lower section of the Plata Basin during summer (lotic water bodies). Otolith $\mathrm{Sr}$ : Ca ratio of silversides from the Paraná River Delta was associated with the conductivity of water at the locations where the sample was collected. According to this association and the obtained results in the calibration curve, the silversides were displaced from zones where conductivity was 7.45 $\left(\mathrm{mS} \mathrm{cm}^{-1}\right)$, corresponding to the water $\mathrm{Sr}$ : Ca ratio in the outer section of the Río de la Plata River $\left(1.92 \mathrm{mmol} \mathrm{mol}^{-1}\right)$. The high values of otolith $\mathrm{Sr}$ : Ca ratio found for some fish may indicate that during summer they moved from estuarine waters where salinity increases gradually to the Argentinian Sea.
\end{abstract}

Additional keywords: estuarine, Odontesthes bonariensis.

Received 23 June 2012, accepted 5 March 2013, published online 5 July 2013

\section{Introduction}

The Río de la Plata estuary is a freshwater-marine environment receiving the waters of the vast the Plata Basin, which is the fourth largest basin of the world, with an area of $3170000 \mathrm{~km}^{2}$. This basin includes Argentina, Brazil, Uruguay and Paraguay (South America). The Río de la Plata River, which covers an area of $30362 \mathrm{~km}^{2}$, discharges an average of $23000 \mathrm{~m}^{3} \mathrm{~s}^{-1}$ into the sea (Guerrero et al. 2010). It is divided into three sections along the freshwater-marine gradient: the inner, middle or transition and outer sections (Fig. 1), according to different characteristics (water quality, geomorphology and ecology; FREPLATA 2005). The inner - freshwater - section has a salinity lower than $0.2 \mathrm{~g} \mathrm{~L}^{-1}$ and the coarsest sediments, while the middle or transition section shows salinities ranging between 0.04 and $10 \mathrm{~g} \mathrm{~L}^{-1}$ and fine sediments. The outer section has salinities between 5 and $25 \mathrm{~g} \mathrm{~L}^{-1}$ and is characterised by sediments bordering a large sandy body (Urien 1967; Guerrero et al. 2010). This section extends from the continental coast to the $50-\mathrm{m}$ isobath and includes a salt wedge (marine water intrudes beneath the fresh water and lies close to the bottom).
The salt-wedge intrusion is best developed before reaching 'Barra del Indio', a bar of $\sim 100 \mathrm{~km}$ placed along a line from Punta Piedras (Argentina) to Montevideo (Uruguay) (Fig. 1). The location of the salt wedge is mainly determined by bathymetry, but it is also influenced by increasing flow rate. The main forcing factors in the system are the strong south-easterly winds, as they homogenise the water column (Guerrero and Piola 1997).

This freshwater-marine environment supports a great diversity of fish species, including 19 Chondrichthyes, 170 freshwater teleosts and 73 marine teleosts (García et al. 2010). Some species, such as the shad (Prochilodus lineatus), the whitemouth croaker (Micropogonias furnieri) and the silverside (Odontesthes bonariensis), constitute important fisheries. These species entail different management challenges because there are regulations for the shad and whitemouth croaker but not for the silverside. Therefore, it is essential to develop tools contributing to the sustainable management of fishery stocks (each of which is defined as a fish population unit with genetic integrity). 

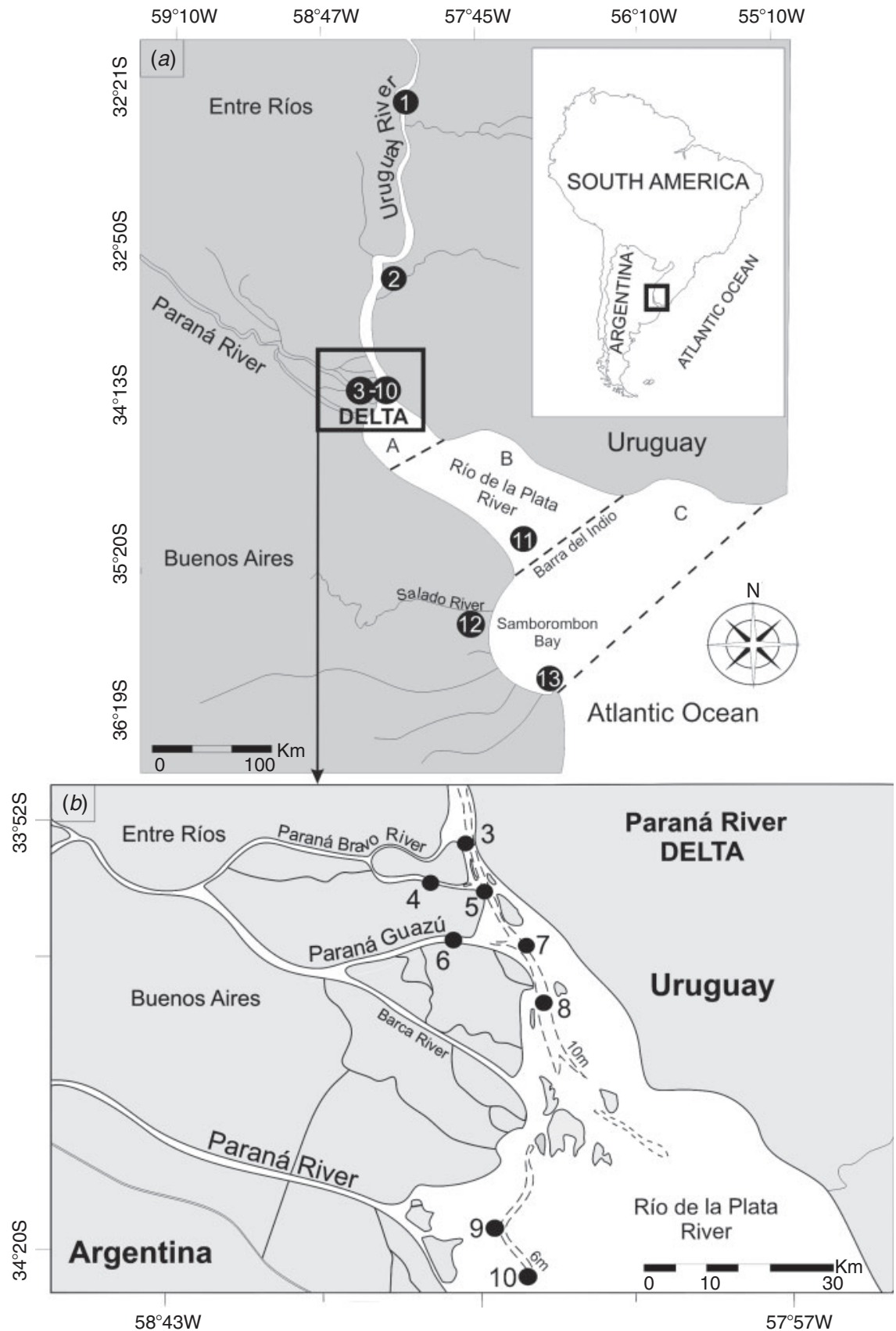

Fig. 1. Sampling sites. (a) Numbers indicate the sampling sites of water (1-13) and fish (3-10) in lower section of the Plata Basin. A, Inner section (freshwater environment); B, Middle section (estuarine environment); and $\mathrm{C}$, Outer section of the Río de la Plata River (estuarine-marine environment). (b) Black circles indicate sampling sites of water and fish in the Paraná River Delta.

The silverside is widely distributed in continental waters of South America (Argentina, Bolivia, Brazil, Chile, Uruguay and Perú), as a result of both natural and anthropogenic factors (Tombari and Volpedo 2008). The silversides' physiological plasticity allows for its tolerance to high salinity (López et al. 2005; Solari et al. 2009; Kopprio et al. 2010).

In Paraná River Delta, inner section of the Río de la Plata River, and Uruguay, Paraná Guazú and Paraná Rivers (Argentina), the silverside is usually present approximately between April and September. During this period, which may vary slightly depending on local climatic conditions, the silverside undergoes reproduction and spawning, and commercial and sport fishing activities are carried out. Its distribution during summer (from November to March) is unknown because of the lack of official and representative capture records.

In the last decade, migration routes and displacements of different fish species were studied by relating water-quality parameters (presence of trace elements and salinity) to otolith 
chemical composition (Secor et al. 1995; Tsukamoto and Arai 2001; Zlokovitz et al. 2003; Tabouret et al. 2010). Fish otoliths are complex polycrystalline structures, composed of calcium carbonate $(\sim 96 \%)$ precipitated in the form of aragonite, and small quantities of other minerals, embedded within a protein matrix (Campana et al. 1997). This structure, which is placed in the inner ear of fish, is involved in hearing and maintenance of equilibrium (Popper and Zhongmin 2000).

The otolith strontium:calcium $(\mathrm{Sr}: \mathrm{Ca})$ ratio is used to reconstruct migration routes or displacements of the stocks along freshwater, estuarine and marine environments, assuming that the otolith $\mathrm{Sr}$ : Ca ratio increases with increasing salinity (Secor et al. 1995; Zlokovitz et al. 2003; Kraus and Secor 2004; Schuchert et al. 2010; Tabouret et al. 2010).

Kraus and Secor (2004) found a direct, positive relationship between the otolith $\mathrm{Sr}$ : $\mathrm{Ca}$ ratio and water $\mathrm{Sr}$ : $\mathrm{Ca}$ ratio. The analysis of otolith $\mathrm{Sr}: \mathrm{Ca}$ ratio is useful for studying fish displacements only if the concentrations of these elements remain relatively stable over time to ensure that the concentrations incorporated into the matrix of the otolith properly reflect the characteristics of the water masses. Moreover, the dispersal of species moving along environments with different salinity (mesohaline, oligohaline or polyhaline areas) over short periods (e. g. 1 week) would not be reflected in the otoliths (Secor et al. 1995).

In brief, the otolith $\mathrm{Sr}: \mathrm{Ca}$ ratio is closely related to the salinity gradient of the freshwater-marine environment and therefore, it can be used to reconstruct migration routes along this environment. The objective of this study is to evaluate some water parameters ( $\mathrm{Sr}$ : Ca ratio, salinity and conductivity) in a freshwater-marine environment (Paraná River Delta, Río de la Plata River and Uruguay, Paraná Guazú and Paraná Rivers) and the otolith $\mathrm{Sr}$ : Ca ratio of a salt-tolerant species (the silverside, O. bonariensis) caught in the Paraná River Delta, in order to contribute to the knowledge of its seasonal movements.

\section{Materials and methods}

Silversides $(n=183)$ were captured in the Paraná River Delta (site numbers 3-10) between May and September 2010 (Fig. 1). Fish were measured for total length $(\mathrm{cm})$ and stored at $-4^{\circ} \mathrm{C}$ until otolith removal. Water and fish samples were collected simultaneously (Fig. 1). In August 2011 additional water samples were taken from the localities of Concepción del Uruguay (Entre Ríos, Argentina, site number 1), Fray Bentos (Uruguay, site number 2), Punta Indio (Buenos Aires, Argentina, site number 11), Río Salado (Samborombón Bay, Argentina, site number 12) and Punta Rasa (Buenos Aires, Argentina, site number 13) (Fig. 1). Conductivity was recorded in situ with a portable meter (HI9033W, HANNA, Italy).

Water samples were preserved by addition of $2 \mathrm{~mL}$ of nitric acid per L of sample (method 3010-B; APHA 1993) and kept at $4^{\circ} \mathrm{C}$ until further analysis. Samples were filtered to remove suspended solids that could interfere with the determination of $\mathrm{Sr}$ concentration. The concentration of $\mathrm{Sr}$ was determined by inductively coupled plasma-atomic emission spectrometry (ICP-OES, Perkin Elmer Optima 2000 DV optical emission spectrometer, Überlingen, Germany ; method EPA 200.7). The instrument was cleaned at regular intervals with MilliQ water (Millipore, São Paulo, Brazil) and $10 \%$ nitric acid matrix to

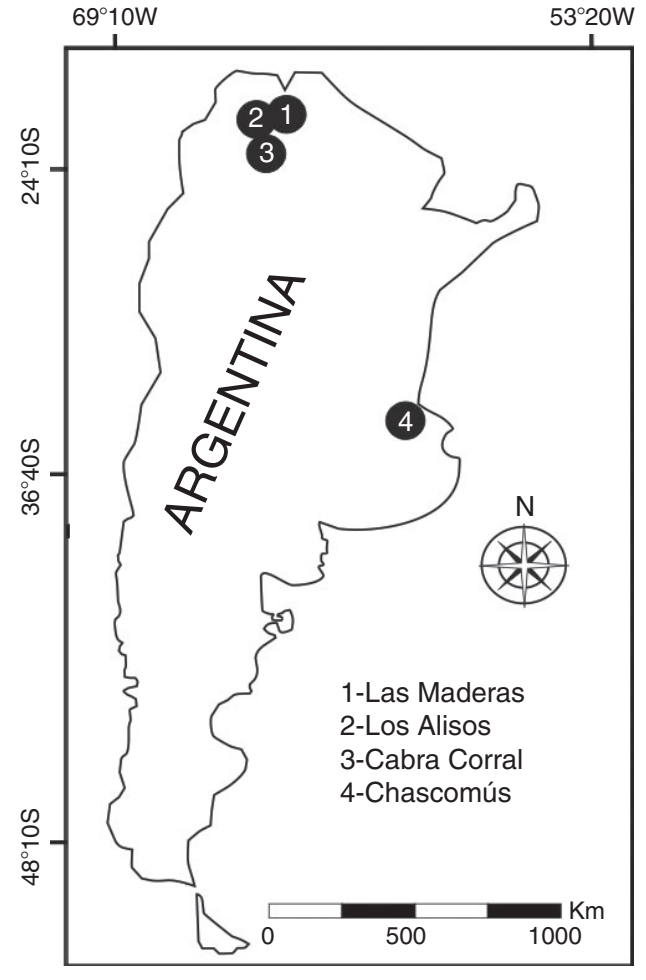

Fig. 2. Sampling sites. Numbers indicate the sampling sites of water and fish in lentic waterbodies.

prevent sample memory effects. The concentration of Ca was determined by titration with ethylenediaminetetraacetic acid (EDTA) (APHA 1993). All measurements were made in triplicate (standard deviation less than $4 \%$ ).

\section{Preparation of otoliths and determination of Sr and Ca}

The pair of otoliths from each fish (183 pairs) was removed, cleaned with distilled water and dried. Then, the otoliths were weighed with an analytical balance to an accuracy of $0.001 \mathrm{~g}$. Photographs were made with a digital camera attached to a stereoscopic microscope. Sixty pairs of otoliths belonging to specimens collected in locations distant from each other were selected for digestion with $50 \%$ nitric acid, and heated on a sand bath at $400-450^{\circ} \mathrm{C}$. The concentrations of $\mathrm{Sr}$ and $\mathrm{Ca}$ were determined as described above and measurements were also made in triplicate (standard deviation less than $4 \%$ ).

\section{Calibration curve}

A calibration curve of water $\mathrm{Sr}: \mathrm{Ca}$ ratio versus otolith $\mathrm{Sr}: \mathrm{Ca}$ ratio from four water bodies was made to investigate silverside displacements in the lower section of the Plata Basin during summer (December to March). Data were obtained from four isolated lentic water bodies having no connection with large rivers or with environments where fish could undergo long-distance dispersal. These water bodies were as follows ( $n=$ number of fish specimens): Los Alisos $(n=16)$ and Las Maderas dam $(n=15)$ in the province of Jujuy; Cabra Corral reservoir $(n=15)$ in the province of Salta; and Chascomús shallow lake $(n=19)$ in the province of Buenos Aires, Argentina (Fig. 2). Fish and water samples were collected in each water 


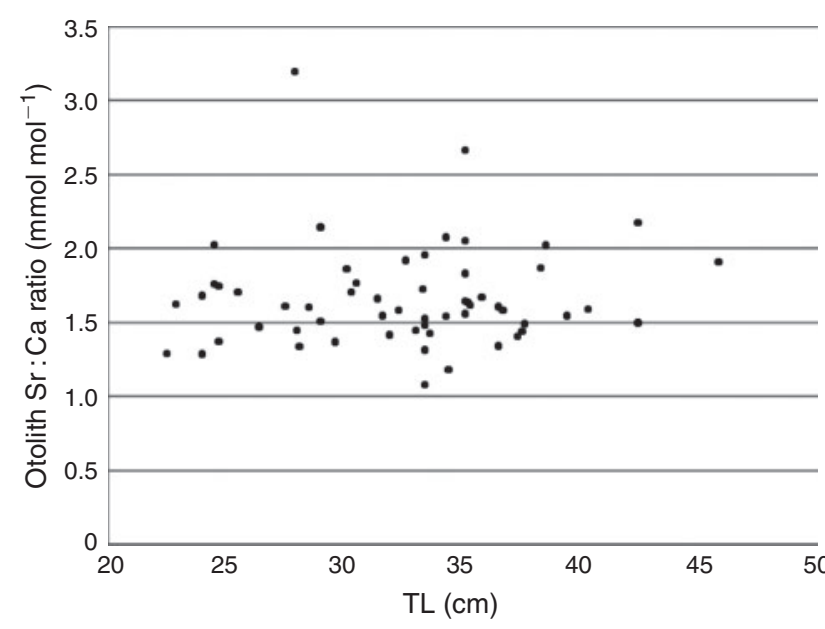

Fig. 3. Relationship between otolith $\mathrm{Sr}$ : $\mathrm{Ca}$ ratio $\left(\mathrm{mmol} \mathrm{mol}^{-1}\right)$ and total length (TL) of fish $(n=60)$ captured in the Paraná River Delta (sities 3-10).

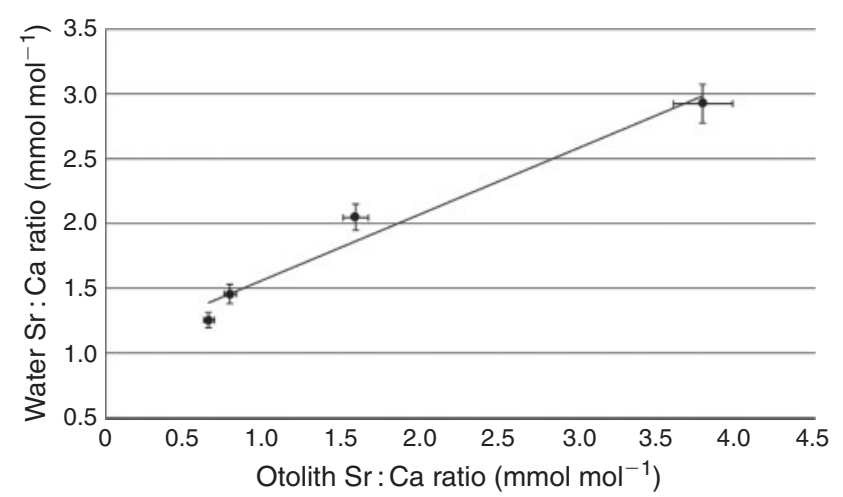

Fig. 4. Fitted regression line between the water $\mathrm{Sr}$ : Ca ratio of the different studied lentic water bodies and the otolith $\mathrm{Sr}: \mathrm{Ca}$ ratio $\left(\mathrm{mmol} \mathrm{mol}^{-1}\right)$ of silversides (sites 1-4, Fig. 2). $P=0.016 ; R^{2}=0.97$. All measurements were made in triplicate. Bars indicate the standard deviation.

body to estimate the mean $\mathrm{Sr}$ : Ca ratio of otoliths and water. For each environment of the lower section of the Plata Basin, the average otolith $\mathrm{Sr}$ : $\mathrm{Ca}$ ratio was determined and the corresponding mean water $\mathrm{Sr}$ : $\mathrm{Ca}$ ratio was calculated by interpolation using the calibration curve mentioned above.

\section{Results}

Otolith Sr: Ca ratio of silversides from the Paraná River Delta

There was some variability in otolith $\mathrm{Sr}$ : Ca ratio among silversides from the Paraná River Delta (range 1.08-3.2 $\mathrm{mmol} \mathrm{mol}^{-1}$ ), with specimens of similar size showing different $\mathrm{Sr}: \mathrm{Ca}$ ratios (Fig. 3). The mean otolith $\mathrm{Sr}: \mathrm{Ca}$ ratio was $1.69 \pm 0.36 \mathrm{mmol}$ mol $^{-1}$ (mean \pm s.d.).

\section{Calibration curve}

The equation of the fitted regression line $\left(P=0.016 ; R^{2}=0.97\right)$ between the water $\mathrm{Sr}: \mathrm{Ca}$ ratio of the different studied lentic water bodies and the otolith $\mathrm{Sr}: \mathrm{Ca}$ ratio $\left(\mathrm{mmol} \mathrm{mol}^{-1}\right)$ of silversides was $Y=0.509 X+1.055$ (Eqn 1; Fig. 4).
Table 1. Sampling sites ordered along a latitudinal (north-south) gradient, with their respective water $\mathrm{Sr}$ : Ca ratios and conductivities The values for the Paraná River Delta were obtained by averaging data from eight samples

\begin{tabular}{lcc}
\hline Sampling sites & $\begin{array}{c}\text { Water Sr: Ca ratio } \\
\left(\mathrm{mmol} \mathrm{mol}^{-1}\right)\end{array}$ & $\begin{array}{c}\text { Conductivity } \\
\left(\mathrm{mS} \mathrm{cm}^{-1}\right)\end{array}$ \\
\hline (1) Concepción del Uruguay & 0.52 & 0.056 \\
(2) Fray Bentos & 0.71 & 0.067 \\
(3-10) Paraná River Delta & 1.18 & 0.084 \\
(11) Punta Indio & 1.66 & 0.51 \\
(12) Canal 15 & 2.26 & 17 \\
(13) Punta Rasa & 2.68 & 30.30 \\
\hline
\end{tabular}

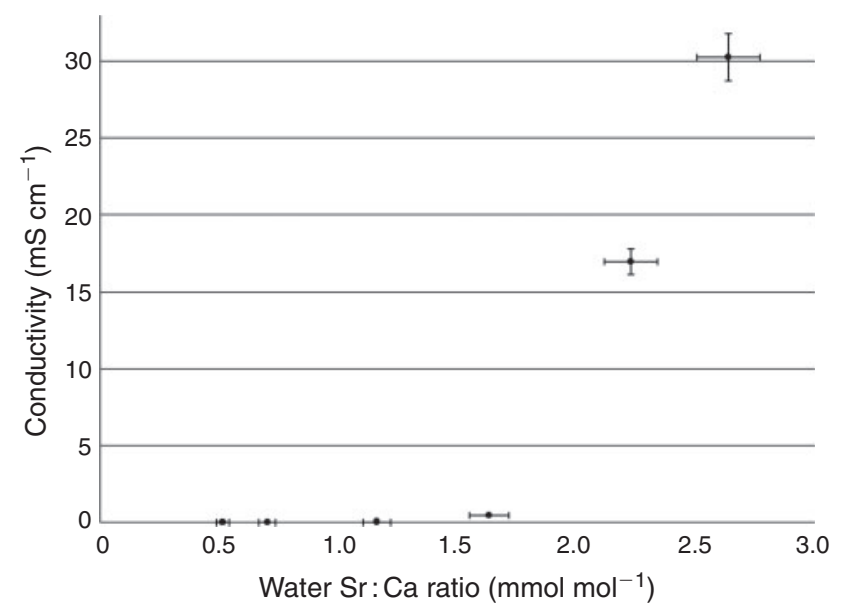

Fig. 5. Quadratic relationship between the water conductivity $\left(\mathrm{mS} \mathrm{cm}^{-1}\right)$ and the water $\mathrm{Sr}$ : Ca ratio $\left(\mathrm{mmol} \mathrm{mol}^{-1}\right)$ in the different sampling sites (sites $1-13$, Fig. 1). $R^{2}=0.98$. All measurements were made in triplicate. Bars indicate the standard deviation.

\section{Water Sr: Ca ratio v. otolith Sr: Ca ratio}

The water Sr: Ca ratio in the Paraná River Delta and the inner section of the Río de la Plata River was $1.18 \pm 0.35 \mathrm{mmol} \mathrm{mol}^{-1}$ (mean \pm s.d.; $n=8$ ). According to Eqn 1, the predicted water $\mathrm{Sr}$ : Ca ratio in the Paraná River Delta and the inner section of the Río de la Plata River corresponding to the mean otolith $\mathrm{Sr}$ : $\mathrm{Ca}$ ratio $\left(1.69 \pm 0.36 \mathrm{mmol} \mathrm{mol}^{-1}\right)$ was $1.92\left(\mathrm{mmol} \mathrm{mol}^{-1}\right)$, with a $95 \%$ confidence interval between 1.56 and 2.28 .

\section{Water Sr: Ca ratio versus conductivity}

The water $\mathrm{Sr}$ : Ca ratio increased with increasing conductivity along a latitudinal (north-south) gradient, with a rapid increment in the outer section of the Río de la Plata River (samples 11, 12 and 13, Table 1). The relationship between conductivity and $\mathrm{Sr}: \mathrm{Ca}$ ratio of water samples collected in different sites in the lower section of the Plata Basin (sites 1-13, Fig. 1) is described by the quadratic equation: $Y=11.81 X^{2}-24.3 X+10.57$ (Eqn 2; Fig. 5).

According to Eqn 2, the predicted conductivity corresponding to the water $\mathrm{Sr}$ : $\mathrm{Ca}$ ratio in the lower section of the Plata Basin $\left(1.92 \mathrm{mmol} \mathrm{mol}^{-1}\right)$ was $7.45\left(\mathrm{mS} \mathrm{cm}^{-1}\right)$. 
Table 2. Values of otolith $\mathrm{Sr}$ : Ca ratio $\left(\mathrm{mmol} \mathrm{mol}^{-1}\right)$ of freshwater and estuarine species. (modified from Secor et al. 1995) $\mathrm{ND}$, not determined

\begin{tabular}{lccll}
\hline & \multicolumn{2}{c}{ Sr:Ca ratio } & Species & Reference \\
& Mean & Range & & \\
\hline Estuarine & 2.3 & ND-4.1 & Morone saxatilis & Secor 1992 \\
& - & $2.5-4$ & Anchoa mitchilli & Secor 1992 \\
Fresh water & 1.69 & $1-3.2$ & Odontesthes bonariensis & This paper (Paraná River Delta, site numbers 3-10, Fig. 1) \\
& 0.78 & $0.34-1.31$ & Odontesthes bonariensis & This paper (Las Maderas Dam, site number 1, Fig. 1) \\
& 0.3 & ND-2.1 & Anguilla anguilla & Casselman 1982 \\
& 0.9 & ND-1.8 & Anguilla rostrata & Casselman 1982 \\
& - & ND-1.0 & Stenobius genivittatus & Radtke et al. 1988 \\
& 0.8 & $0.4-1.0$ & Salmo trutta & Kalish 1989 \\
& 1.1 & $0.3-1.8$ & Oncorhynchus mykiss & Kalish 1990 \\
& 0.6 & ND-2.0 & Morone saxatilis & Secor 1992 \\
\hline
\end{tabular}

\section{Discussion}

The relationship between otolith $\mathrm{Sr}$ : Ca ratio and total length (TL) was slightly variable for silversides from the Paraná River Delta, which suggests that they came from areas with different salinity. The relatively low variability of $\mathrm{Sr}$ : Ca ratio found for some fish (Fig. 3) may indicate that during summer they had moved together, as a group, along estuarine waters (outer section of the Río de la Plata River and Argentine Sea), where salinity increases gradually until reaching the Argentine Sea.

Secor et al. (1995) reviewed the ranges of otolith $\mathrm{Sr}: \mathrm{Ca}$ ratios for freshwater and brackish fish species from the northern hemisphere reported in the literature (Table 2). In the present work, the mean otolith $\mathrm{Sr}$ : Ca ratio $\left(\mathrm{mmol} \mathrm{mol}^{-1}\right)$ of silversides from the Paraná River Delta $\left(1.69 \pm 0.36 \mathrm{mmol} \mathrm{mol}^{-1}\right)$ is within the range for estuarine fish species (undetectable $4.1 \mathrm{mmol} \mathrm{mol}^{-1}$ ), and the maximum value recorded (range 1.08-3.2 $\mathrm{mmol} \mathrm{mol}^{-1}$ ) exceeded the range for freshwater fish species (undetectable $-2.1 \mathrm{mmol} \mathrm{mol}^{-1}$ ) (Table 2). A direct and positive relationship between the otolith $\mathrm{Sr}$ : $\mathrm{Ca}$ ratio and water $\mathrm{Sr}$ : $\mathrm{Ca}$ ratio has also been reported by other authors (Kraus and Secor 2004). The otolith Sr was found to be positively correlated with water salinity (Kraus and Secor 2004), while the otolith $\mathrm{Sr}$ : Ca ratio was shown to be positively and negatively correlated with water temperature above and below $10^{\circ} \mathrm{C}$, respectively (Campana, 1999). The fact that the incorporation of $\mathrm{Sr}$ into the otolith is affected by environmental characteristics makes this element a useful tool to study fish displacements and to discriminate fish stocks (Zlokovitz et al. 2003; Kraus and Secor 2004; Schuchert et al. 2010; Secor et al. 1995; Tabouret et al. 2010).

In the Paraná River Delta, the mean water $\mathrm{Sr}: \mathrm{Ca}$ ratio calculated on data from eight water samples (sites 3-10, Fig. 1) was $1.18 \pm 0.35 \mathrm{mmol} \mathrm{mol}^{-1}$ (mean \pm s.d.). In contrast, the mean water $\mathrm{Sr}: \mathrm{Ca}$ ratio estimated from the otolith $\mathrm{Sr}: \mathrm{Ca}$ ratio according to the calibration curve was $1.92 \mathrm{mmol} \mathrm{mol}^{-1}$ with a $95 \%$ confidence interval between 1.56 and 2.28 . This difference probably results from seasonal displacements of the studied fish. A possible explanation might be that during winter, the fish live in low-salinity waters of the inner or middle sections of the Río de la Plata Basin, while during summer they move south-west towards estuarine waters (outer Río de la Plata River).

For the outer section of the Río de la Plata River, the mean value of conductivity according to the quadratic relationship between conductivity and water $\mathrm{Sr}$ : Ca ratio was $7.45 \mathrm{mS} \mathrm{cm}^{-1}$. The outer section of the Río de la Plata River, from Barra del Indio to the outer limit of the Río de la Plata River (Fig. 1), includes the Samborombón Bay, which is characterised by salinity lower than $15 \mathrm{~g} \mathrm{~L}^{-1}$ (Guerrero et al. 2010). Solari et al. (2009) reported the presence of $O$. bonariensis in the Samborombón Bay and in some of its affluents, such as the Ajo and Salado Rivers, where salinity is highly variable $\left(0.57-4.3 \mathrm{~g} \mathrm{~L}^{-1}\right)$ and depends on tides (Carol et al. 2008). This suggests that during summer, silversides could be found to the south-east of Barra del Indio rather than in the Paraná River Delta or upstream in the main tributaries of the Río de la Plata River (Fig. 1).

In autumn and winter, the Río de la Plata River discharges mainly to the Uruguayan coast, which provokes a decrease in the salinity of the surface waters, while in spring and summer it discharges to the Argentine coast (Guerrero et al. 2010). Then, it is reasonable to assume that fish may move along the Argentine coast southward until reaching the Samborombón Bay (mixohaline waters) in early spring and along the Uruguayan coast towards the Delta (less saline waters) in early autumn, depending on the influence of the Río de la Plata River. In winter, the silverside may be distributed throughout the large rivers of the Delta, including the Uruguay River, up to the northern region of Entre Rios Province and the Paraná River up to Corrientes Province. López et al. (2005) reported the presence of silversides in this area during winter. However, there is no information available on the presence of silversides in this area during summer. The main hypothesis is that silversides could be in estuarine water (south-east of Barra del Indio) during summer.

\section{Acknowledgements}

Financial support was provided by Universidad de Buenos Aires, Argentina (UBACYT CC05 and UBACYT 20620110100007) and National Agency for Promotion of Science and Technology (ANPCyT) (PICT 2010-1372) and National Council for Scientific and Technological Research (CONICET). 


\section{References}

APHA (1993). 'Standard Methods for the Examination of Water and Wastes. (American Public Health Association: Washington, DC.)

Campana, S. (1999). Chemistry and composition of fish otoliths: pathways, mechanisms and applications. Marine Ecology Progress Series 188, 26-297.

Campana, S. E., Thorrold, S. R., Jones, C. M., Gunther, D., Tubrett, M., Longerich, H., Jackson, S., Halden, N. M., Kalish, J. M., Piccolo, P., de Pontual, H., Troadec, H., Panfili, J., Secor, D. H., Severin, K. P., Sie, S. H., Thresher, R., Teesdale, W. J., and Cambell, J. L. (1997). Comparison of accuracy, precision and sensitivity in elemental assays of fish otoliths using the electron microprobe, PIXE and laser ablation ICPMS. Canadian Journal of Fisheries and Aquatic Sciences 54, 2068-2079.

Carol, E., Kruse, R., and Pousa, J. (2008). Environmental hydrogeology of the southern sector of the Samborombon Bay wetland, Argentina. Environmental Geology 54, 95-102. doi:10.1007/S00254-007-0796-5

Casselman, J. M. (1982). Chemical analyses of the optically different zones in eel otoliths. Ontario Fisheries Technical Report Series 4, 74-82.

FREPLATA (2005). Análisis de Diagnóstico Transfronterizo del Río de la Plata y su Frente Marítimo. Proyecto Protección Ambiental del Río de la Plata y su Frente Marítimo: Prevención y Control de la Contaminación y Restauración de Hábitats. Technical report. PNUD, Buenos Aires, Argentina.

García, M., Jaureguizar, A., and Protogino, L. (2010). From fresh water to the slope: fish community ecology in the Río de la Plata and the sea beyond. Latin American Journal of Aquatic Research 38, 81-94. doi:10.3856/VOL38-ISSUE1-FULLTEXT-8

Guerrero, R. A., and Piola, A. (1997). Masas de agua de la plataforma continental. El mar argentino y sus recursos pesqueros 1, 107-119.

Guerrero, R. A., Piola, A. R., Molinari, G., and Osiroff, A. P. (2010). 'Climatología de temperatura y salinidad en el Río de la Plata y su Frente Marítimo, Argentina-Uruguay.' 1st edn. (Instituto Nacional de Investigación y desarrollo Pesquero: Mar del Plata, Argentina.)

Kalish, J. M. (1989). Otolith microchemistry: validation of the effects of physiology, age and environmenton otolith composition. Journal of Experimental Marine Biology and Ecology 132, 151-178. doi:10.1016/0022-0981(89)90126-3

Kalish, J. M. (1990). Use of otolith microchemistry to distinguish progeny of sympatric anadromous and non-anadromous salmonids. Fish Bulletin 88, 657-666.

Kopprio, G. A., Freije, R. H., Strüssmann, C. A., Kattner, G., Hoffmeyer, M. S., Popovich, C. A., and Lara, R. J. (2010). Vulnerability of pejerrey Odontesthes bonariensis populations to climate change in pampean lakes of Argentina. Journal of Fish Biology 77, 1856-1866. doi:10.1111/J.1095-8649.2010.02750.X

Kraus, R. T., and Secor, E. R. (2004). Incorporation of strontium into otoliths of an estuarine fish. Journal of Experimental Marine Biology and Ecology 302, 85-106. doi:10.1016/J.JEMBE.2003.10.004
López, H. L., Miquelarena, A. M., and Ponte Gómez, J. (2005). Biodiversidad y Distribución de la Ictiofauna Mesopotámica. In 'Temas de la Biodiversidad del Litoral fluvial argentino II'. (Ed. F. G. Aceñolaza) pp. 311-354. (INSUEGO Micelánea: Tucumán, Argentina.)

Popper, A. N., and Zhongmin, L. (2000). Structure-function relationship in fish otolith organs. Fisheries Research 46, 15-25. doi:10.1016/S01657836(00)00129-6

Radtke, R. L., Kinzie, R. A., and Folsom, S. D. (1988). Age at recruitment of Hawaiian freshwater gobies. Environmental Biology of Fishes 23, 205-213. doi:10.1007/BF00004911

Schuchert, P. C., Arkhipkin, A. I., and Koenig, A. E. (2010). Traveling around Cape Horn: Otolith chemistry reveals a mixed stock of Patagonian hoki with separate Atlantic and Pacific spawning grounds. Fisheries Research 102, 80-86. doi:10.1016/J.FISHRES.2009.10.012

Secor, D. H. (1992). Application of otolith microchemistry analysis to investigate anadromy in Chesapeake Bay striped bass Morone saxatilis. Fish Bulletin 90, 798-806.

Secor, D. H., Henderson-Arzapalob, A., and Piccoli, P. M. (1995). Can otolith microchemistry chart patterns of migration and habitat utilization in anadromous fishes? Journal of Experimental Marine Biology and Ecology 192, 15-33. doi:10.1016/0022-0981(95)00054-U

Solari, A. L., Mirta, L., García, L., and Jaureguizar, A. (2009). Fish fauna from the Ajó river in Campos del Tuyú National Park, province of Buenos Aires, Argentina. Check List 5, 807-811.

Tabouret, H., Bareille, G., Clverie, F., Pecheyran, C., Prouzet, P., and Donard, O. F. (2010). Simultaneous use of strontium:calcium and barium:calcium ratios in otoliths as markers of habitat: application to the European eel (Anguilla anguilla) in Adour Basin, South West France. Marine Environmental Research 70, 35-45. doi:10.1016/ J.MARENVRES.2010.02.006

Tombari, A., and Volpedo, V. A. (2008). Modificaciones en la distribución original de especies por impacto antrópico: el caso de Odontesthes bonariensis (Pisces:Atherinopsidae). In 'Efecto de los cambios globales sobre la biodiversidad'. (Eds V. A. Volpedo and L. Fernández Reyes.) pp, 155-165. (Buenos Aires, Argentina.)

Tsukamoto, K., and Arai, T. (2001). Facultative catadromy of the eel Anguilla anguilla between freshwater and seawater habitats. Marine Ecology Progress Series 220, 265-276. doi:10.3354/MEPS220265

Urien, C. M. (1967). Los sedimentos modernos del Río de la Plata Exterior. Boletín del Servicio de Hidrografía Naval 4, 113-313.

Zlokovitz, E. R., Secor, D. H., and Piccoli, P. M. (2003). Patterns of migration in Hudson River striped bass as determined by otolith microchemistry. Fisheries Research 63, 245-259. doi:10.1016/S0165-7836 (03)00069-9 